\title{
AZ ONLINE MATEMATIKATANÍTÁS TAPASZTALATAI
}

\section{EXPERIENCES IN ONLINE MATHEMATICS TEACHING}

\author{
Baranyai Tünde Klára, Debrenti Edith
}

\begin{abstract}
Due to the coronavirus epidemic, authorities ordered quarantine in most European countries, including us as well from March 2020. As a consequence, both school and university education was moved to homes which challenged teachers, children and parents seriously. The 2020-2021 school year is currently proceeding under the same circumstances: some schools are following the hybrid model, others are teaching under normal school conditions, whereas others are online (e.g. most universities). In our research, we aimed to find out how mathematics was taught online. In more details, the study extended to the platforms used for online teaching of mathematics, to the teaching and evaluation strategies, to the advantages and disadvantages of online teaching.
\end{abstract}

The first phase of the research was carried out in October 2020. The research tool was an online questionnaire sent to the participants using the 'snowball-method'. The questionnaire was filled by 201 students from three universities: Partium Christian University Oradea, Babeș-Bolyai University (ClujNapoca and Satu Mare) and Debrecen University. All these students had mathematical courses in their curriculum this year. The results of this phase show that the majority of the students have adapted to online mathematics education and most of them get the assignments weekly. They can see the positive side of the situation as well, such as the easier access to the curriculum. According to the students, the majority of the tutors are prepared for teaching online, the tasks can be solved individually as well as, they also manage to learn mathematical concepts online. In the second phase of research, we compared the exam results of the students based on the results of the last two semesters. We were curious whether there were any differences between the results of the offline and the following online semesters. The participants of the research are the first and second-year students of the Economics Department of the Partium Christian University $(\mathrm{N}=79)$, who studied basic mathematics: mathematical analysis, differential calculus, linear algebra and statistics. We assumed that during the online semester course, the performance of the students had declined compared to the previous offline semester since teaching was more difficult as well as the exam was stricter. We applied significance testing in the one-group pedagogical research. The assessment showed that there was no significant difference between the average of the offline and the online semesters.

Keywords: mathematics teaching, online teaching, university education

\section{Bevezetés}

A koronavírus-járvány miatt a 2019-2020-as tanév márciusától a legtöbb európai országban, így Romániában is karantént rendeltek el, ennek következményeként az iskolai és az egyetemi oktatás az online térbe költözött, komoly kihívást jelentve úgy a tanárok, mint a gyermekek és a szülök számára egyaránt. A Covid-19 járvány, korábban ismeretlen tapasztalatok sorozatát generálta: bezárásokat (beleértve az iskolák bezárását), otthoni munkavégzést teljes vagy részmunkaidőben. Az ismeretlen ellenségtől való félelem felforgatta az életet az egész világon. Ezek az események a bekövetkezett társadalmi változások kapcsán elgondolkodtatnak. A tudósok egyetértenek abban, hogy a járvány következményeként már történtek változások (online tanítás, az iroda, mint munkatér átalakulása, 
országhatárok lezárása stb.), azonban csak akkor spekulálhatunk azon, hogy mely változások vezetnek állandó társadalmi átalakuláshoz, amikor a világjárvány véget ér, és az élet visszatér a normális kerékvágásba (Nistor, Gergely, Sántha, Telegdy, 2020).

A 2020-2021-es tanévet is nagy mértékben befolyásolta a világjárvány, bizonyos iskolákban hibrid oktatással kezdődött a tanítás, van, ahol zavartalanul élőben, normális iskolai keretek között, illetve van, ahol kizárólag online oktatás formájában, így a legtöbb egyetemen is.

Kutatásunk első részében arra kerestük a választ, hogyan viszonyulnak az egyetemi hallgatók és az oktatók a matematika online oktatásához, hogyan sikerült alkalmazkodni a kialakult helyzethez, milyen platformokat használtak, mennyi önálló munkát kapnak, és véleményük szerint hogyan sikerült elsajátítani a matematikai fogalmakat. A kutatásunk második részében arra voltunk kíváncsiak, hogy befolyásolja-e a megváltozott helyzet, az online oktatás bevezetése a hallgatók matematika vizsgán elért eredményeit, van-e szignifikáns különbség az offline, illetve az azt követő online félév során szerzett érdemjegyek között.

\section{Elméleti háttér}

Megvizsgáltuk a témában megjelent friss kutatások eredményeit, melyek az online oktatás témakörével, illetve a koronavírus teremtette helyzettel foglalkoznak.

Az online oktatás eltér a hagyományos oktatástól, ez az új oktatási környezet különböző módszereket és ötleteket alkalmaz. Az egyetemi oktatónak fel kell készülnie a szoftverek alkalmazására, ismernie kell a technikai eszközeit, kényelmesen kell használnia a számítógépeket, és képesnek kell lennie a technikai problémák kezelésére. Tábla helyett a számítógép képernyőjét és webkameráját kell használni, új feladatokat kell elvégezni új módszerekkel, tanítani az osztályban, miközben követni kell a szöveges csevegést, és figyelni, hogy a hallgatók „emeljék fel a kezüket”. Új módszereket kell találnia, hogy megérezhesse diákjainak teljesítőképességét, azon kívül, hogy üres arcukat nézi. Az alkalmazandó módszerekkel kapcsolatos ötleteket más emberektől, kollégáktól kell összegyüjtenie, akik hasonló órákat tartanak. Használni kell a szöveges chat funkciókat, elektronikus formában kell kiosztania és javítania a feladatokat, törekednie kell a gyors visszacsatolásra, fel kell építenie egy közös munkát a hallgatókkal, elérhetőnek kell lennie a hallgatók számára, illetve meg kell teremtenie a lehetóséget arra, hogy hallgatókat személyesen is megismerje (Gleason, 2006). A digitális toll (elektronikus ceruza) technológia használata a hallgatók és oktatók által az online matematika órán növelheti a kommunikációt és az interakciót a tanulási környezetben.

Az online matematika tanítás digitális toll használata nélkül interaktivitási és pedagógiai szempontból bizonyos korlátokat eredményezhet. Használata a tananyag tartalmának magyarázata során megkönnyíti az óra tervezését és lefolyását, a fogalmak, szimbólumok és a megoldási folyamat lépéseinek megjelenítéséhez, elegendő visszacsatoláshoz, magas szintű interakció eléréséhez és hatékonyabb oktatáshoz vezet. Lehetővé teheti a tanár-diák interakció maximalizálását, kiküszöböli az elszigeteltség érzését egy online tanulási környezetben, és megkönnyíti a matematikai kérdések megoldási folyamatának digitális környezetben történő megjelenítését. Emellett kompatibilis szoftvert kell kifejleszteni, hogy az oktató hozzáférhessen a hallgatók munkáihoz és a hallgatók által egy adott platformon készített jegyzetekhez. Ily módon az osztálytermi ellenőrzés könnyebben fenntartható, és az oktatók azonnali visszajelzést adhatnak a hallgatóknak alkalmazásuknak és válaszaiknak megfelelöen (Karal et al, 2015).

Egy idei kutatásban a petrozsényi egyetem 209 hallgatóját kérdezték meg a tavaszi félév során (Edelhauser, Lupu-Dima, 2020). A tanulmány szerint az egyetem hallgatói gyorsan alkalmazkodtak az online oktatáshoz, $87 \%$-a a megkérdezett hallgatóknak részt vett a 2020 március-májusi időszakban tartott online órákon. A hallgatók 42\%-a az okostelefonját használta az online anyagok olvasására és értekezletekhez való bejelentkezéshez. Az előadások 50\%-a volt online módon lefedve, illetve 30\%-a a kurzusoknak volt videóértekezlet formájában megtartva.

Egy másik kutatásban (Lokanath, Gupta, Shree, 2020), amit indiai egyetemi oktatók és hallgatók körében végeztek, a szerzők arra hívják fel a figyelmet, hogy az oktatás minőségét meg kell tartanunk, új tantervet kell kidolgozni az online oktatás számára, a hallgatók kritikai gondolkodására kell 
építenünk, fontos a videós online órák tartása, melyek alkalmával, a hallgatókat is be kell vonnunk a tanítási folyamatba, valamint az értékelés fontosságáról is szó esik. Egy, szintén friss tanulmány szerint egyelőre annyi biztos, hogy a normalitás fel van függesztve, de senki sem tudja mennyi ideig (Giordano, 2020).

A Partiumi Keresztény Egyetemen a 2019-2020-as akadémiai tanév végén, az online oktatás féléves tapasztalatait és tanulságait kutatták, úgy az egyetemi oktatók, mind a hallgatók körében (Gál, Pásztor, Székedi, Tolnai, 2020). Az oktatói kérdőívet 77 tanár töltötte ki, a legfontosabb eredmények az online oktatási tapasztalatait illetően a következők: a tanárok többsége azt nyilatkozta, hogy az online oktatás beállta előtt nem vett részt online kurzuson, képzésen, tréningen, és az online oktatás többletmunkát igényelt a karantén ideje alatt. A megkérdezettek többsége kapott segítséget az online oktatás során felmerült problémák megoldásában (tanszéki, kari, egyetemi szinten, kollégáktól, informatikustól, másoktól). A használt platformok, amelyekről nyilatkoztak, igen változatosak. Az interaktív online órák megtartására a Google Meet a legtöbbet használt felület. Az online kurzusok biztosítására alkalmas platformok közül a Moodle és a Google Classroom az a két felület, amelyet a kutatás résztvevői a legtöbbet használnak és ezeket a felületeket választották, amikor azt kérdezték, hogy melyik felületeket kellene még fejleszteni, hogy az egyetem hivatalos, online oktatásra alkalmas platformjai legyenek. A megkérdezett oktatók elsöprő többsége igényelné az online oktatással kapcsolatos képzések megszervezését: mind a technikai dimenziót, mind pedig a tartalmi, módszertani dimenziót fontosnak tartják.

A kutatás következtetései között szerepel, hogy az oktatók mind a Moodle, mind pedig a Google Classroom, mint online kurzusok biztosítására alkalmas felületet kedvelik, használják - ennek a kettőnek a működtetésére kellene ráállni, az oktatók szerint mindkettőnek megvannak az előnyei és hátrányai. Az oktatók javaslatai között szerepel, hogy az őszi félév során képzéseket szervezzenek számukra, jó lenne egy, az online oktatás módszertanának elsajátítását/elmélyítését célzó képzést is megszervezni, egy erre alkalmas módszertani szakértő személyében. Úgy tủnik, hogy ilyen jellegü útbaigazítást is nagyon igényelnek az oktatók. (Gál, Pásztor, Székedi, Tolnai, 2020).

\section{A hallgatók véleménye az online matematika oktatásról}

\subsection{A kutatás leírása}

A kutatás 2020 októberében zajlott.

A kutatás célja: Feltérképezni az egyetemi hallgatók tapasztalatait és véleményét a matematika online tanításával kapcsoltban.

\section{A kutatás kérdései}

Kutatásunkban az alábbi kérdésekre kerestük a választ:

- Milyen stratégiákat, platformokat alkalmaznak az oktatók a kurzusok, illetve a szemináriumok során?

- Hol kapják meg a feladatokat a hallgatók és milyen gyakran?

- Hogyan történik a jegyadás, vizsgáztatás?

- Mi volt a legnagyobb kihívás az online platformok használata során?

- Mennyire hatékonyan sikerül elsajátítani a matematikai tartalmakat online módon?

- Melyek voltak az online oktatás előnyei, hátrányai?

- Hogyan müködtek együtt a csoporttársakkal? 


\section{A kutatás résztvevői}

A vizsgálatban 201 egyetemi hallgató vett részt, a Babes-Bolyai Tudományegyetem (BBTE), a Debreceni Egyetem és a Partiumi Keresztény Egyetem (PKE) különböző karairól.

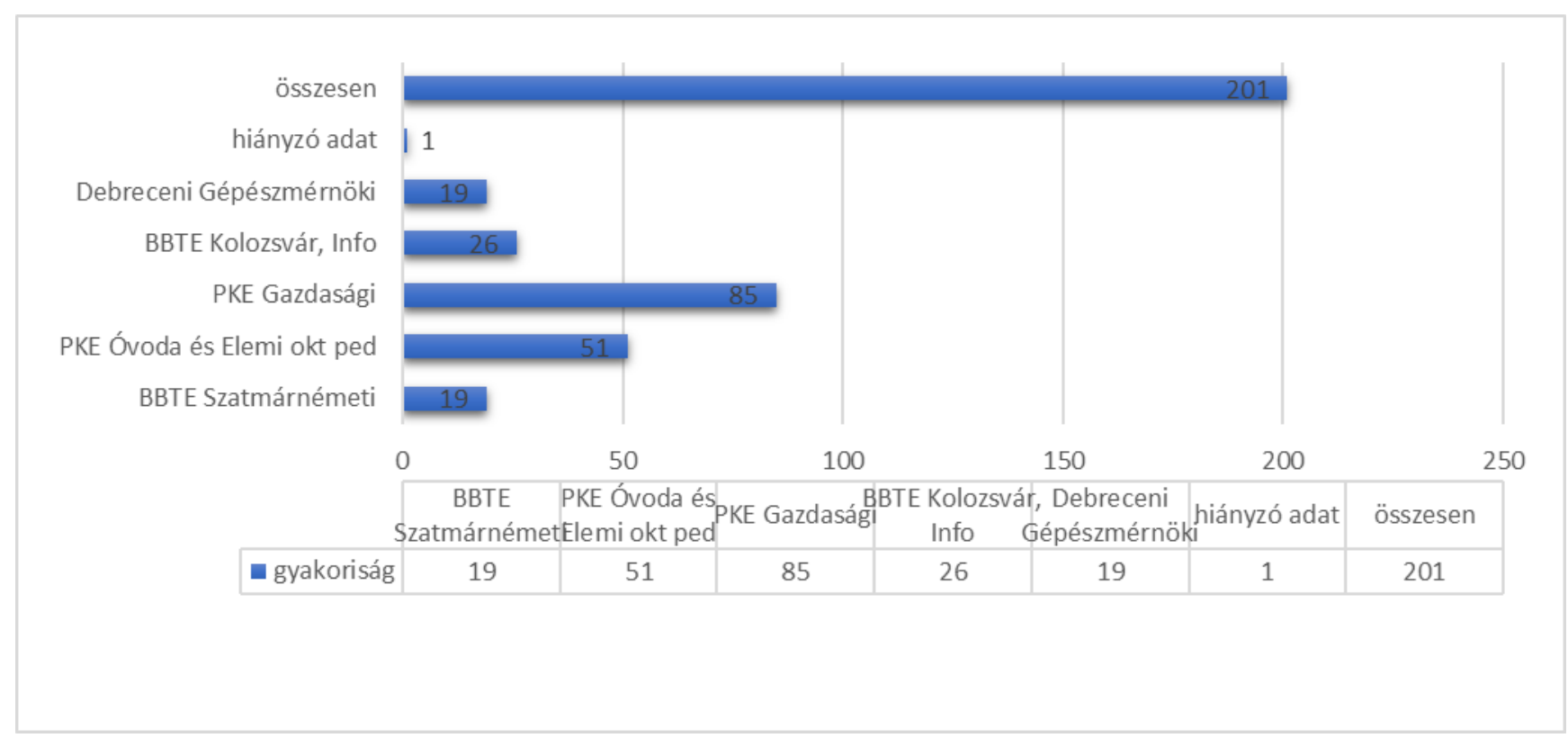

1. ábra Hallgatók szakok/egyetem szerinti eloszlása

A megkérdezett hallgatók $60 \%$-a nő és $40 \%$-a férfi volt. A megkérdezettek nagyobb része, 150 hallgató $(74,63 \%)$ kora a 18-21 év között volt, 13-an (11,44\%) 22-24 év közötti, illetve 27-en $(13,43 \%) 25$ évnél idősebbek. Az alábbi, 1. ábra a hallgatók eloszlását mutatja, hogy milyen egyetemen tanulnak.

Az 1. ábra alapján, a megkérdezett hallgatók a Babeș-Bolyai Tudományegyetem két karán (22,38\%), a Partiumi Keresztény Egyetem két karán $(67,66 \%)$, illetve a Debreceni Egyetem, Nagyváradra kihelyezett szakán $(9,45 \%)$ tanulnak.

A megkérdezett hallgatók 49,25\%-a első éven, 36,31\%-a másodéven, 12,93\%-a harmadéven tanul, illetve a mintában szerepelt egy mesteri képzésben tanuló hallgató is. A mintában szereplö hallgatók 25,87\%-a a 2019-2020 tanév második félévében, 53,23\% a 2020-2021-es tanév első félévében, 19,4\%uk mindkét félévben tanulta a matematikát, hiányzó adatok száma 3, ami a minta 1,49\%-a.

\section{A kutatás eszköze}

Az általunk összeállított online kérdőív 22 kérdést tartalmazott, melyek közül 11 kérdés feleletválasztós, 10 vélemény, illetve egy kifejtős kérdés volt. A feleletválasztós kérdések egy része demográfiai kérdés volt, majd az online oktatással kapcsolatos kérdések következtek, melyek a használt platformokra, a feladatok kiosztásának gyakoriságára vonatkoztak.A kérdőív második felében egy ötfokú Likert-skálát alkalmaztunk, amely 10 kijelentést foglalt magába. A kijelentések a matematika tanításának online formában történő tanításának hatékonyságára, a hallgatótársakkal való közös munkára, az online oktatás nehézségeire vonatkoztak. Az utolsó kérdésben megkértük a hallgatókat, hogy fejtsék ki a véleményüket röviden a matematika online oktatásáról, hogyan lehetne leghatásosabb a matematika tanítása a jelenlegi körülmények között, mennyire vannak megelégedve a megtartott online órákkal? 


\subsection{A kutatás eredményei}

Megkérdeztük azokat a hallgatókat, akik a 2020-2021-es tanév első félévében tanulják a matematikát, hogy milyen rendszerben folyik az oktatás. A kitöltés időpontjában a 168 válaszadó közül 86,3\% online tanulta a matematikát, 6,5\%-uk élőben, valamint 6,5\%-uk hibrid rendszerben tanult, 6 -an pedig az egyéb lehetőséget jelölték meg.

Kíváncsiak voltunk, milyen platformokat használnak az oktatók a kurzusok, illetve szemináriumok esetében, a feladatokat milyen módon juttatják el a hallgatókhoz és hogyan kérik be a hallgatóktól. A kapott eredményeket az 1.táblázatban foglaltuk össze.

1.táblázat: Milyen platformokon tartják az előadásokat/szemináriumokat, illetve hol küldik a feladatokat a hallgatók számára?

\begin{tabular}{|l|l|l|l|l|}
\hline & \multicolumn{1}{|c|}{ Platformok } & & & \\
\hline elöadások & Google Meet & Zoom & MS TEAMS & Egyéb \\
& $127(66,5 \%)$ & $29(15,2 \%)$ & $20(10,5 \%)$ & $15(7,9 \%)$ \\
\hline szemináriumok & Google Meet & Zoom & MS TEAMS & Egyéb \\
& $126(66 \%)$ & $26(13,6)$ & $22(11,5 \%)$ & $17(8,9 \%)$ \\
\hline feladatok & Egyéb & FB csoport & $\begin{array}{l}\text { Google } \\
\text { Classroom }\end{array}$ & MS TEAMS \\
& $96(49,7 \%)$ & $59(30,6 \%)$ & $\begin{array}{l}23(11,9 \%) \\
15(7,9 \%)\end{array}$ \\
\hline
\end{tabular}

$\mathrm{Az}$ 1. táblázat szerint az előadásokat és szemináriumokat az oktatók többsége, a megkérdezett hallgatók esetében a Google Meet platformon tartják meg, illetve használják még a ZOOM és az MS TEAMS platformokat is. A feladatokat az oktatók az évfolyamok Facebook csoportjában jelölik ki (30,6\%), illetve használják a Google Classroom és az MS TEAMS platformokat is. Megkérdeztük a hallgatókat, hogy milyen gyakorisággal kapnak matematikából feladatot, a hallgatók válaszai alapján kijelenthetjük, hogy az oktatók nagy része hetente jelöl ki feladatok a hallgatók számára (77.11\%), két hetente kapnak feladatokat 6-an (2,98\%) illetve az egyébb választ a hallgatók 19,90\%-a választotta.

A kérdőív a matematika online oktatásával kapcsolatos kijelentéseket is tartalmazott, melyekre a hallgatók az 5-ös fokozatú Likert-skála szerint jelölték be véleményüket.

2. táblázat: A matematika online oktatásához kapcsolódó vélemény (5-ös fokozatú Likert skála)

\begin{tabular}{|l|c|c|}
\hline \multicolumn{1}{|c|}{ Kijelentések } & Átlagok & Szórás \\
\hline Nehezemre esett hozzászokni az online matematika órákhoz & 3,27 & 1,34 \\
\hline Az online platformok használata számomra nagy kihívás & 2,21 & 1,29 \\
\hline $\begin{array}{l}\text { A matematikát megfelelő szinten lehet online módon } \\
\text { tanítani, tanulni }\end{array}$ & 2,59 & 1,21 \\
\hline
\end{tabular}




\begin{tabular}{|l|l|l|}
\hline $\begin{array}{l}\text { Az online órákon sikerült elsajátítanom a matematikai } \\
\text { fogalmakat }\end{array}$ & 2,81 & 1,13 \\
\hline $\begin{array}{l}\text { Szerintem szükség lenne arra, hogy az egyetemen tartsuk } \\
\text { meg a matematika órák egy részét }\end{array}$ & 4,01 & 1,24 \\
\hline $\begin{array}{l}\text { Az online óra elónye, hogy az elméleti ismereteket a tanárok } \\
\text { hozzáférhetỏvé teszik }\end{array}$ & 3,85 & 1,19 \\
\hline $\begin{array}{l}\text { A beadandó feladatokkal mindig el vagyok csúszva } \\
\text { sikerül elsajátítanom megfelelöen a tananyagot }\end{array}$ & 2,47 & 1,28 \\
\hline
\end{tabular}

A fenti, 2. táblázat szerint a hallgatók nagymértékben úgy nyilatkoztak, hogy szükség lenne arra, hogy az egyetemen tartsák meg a matematika órákat. Szintén magasabb átlagot kaptak a következő kijelentések: az online órák előnye, hogy az elméleti ismereteket a tanárok hozzáférhetővé teszik, nehezemre esett hozzászokni az online matematika órákhoz, illetve úgy érzem, ha sokáig fog tartani az online oktatás, nem sikerül elsajátítanom megfelelően a tananyagot. Kisebb átlagot kaptak, vagyis kevésbé értenek egyet a hallgatók a következő kijelentésekkel: a beadandó feladatokkal mindig el vagyok csúszva, az online platformok használata számomra nagy kihívás, a matematikát megfelelő szinten lehet online módon tanulni/tanítani és az online órákon sikerült elsajátítanom a matematikai fogalmakat.

Az online kérdőív végén, egy nyitott kérdésben arra kértük a hallgatókat, hogy röviden fogalmazzák meg a véleményüket az online matematikatanítással kapcsolatban. A kapott válaszok közül néhányat szó szerint idézünk, ezek alapján elmondhatjuk, hogy a hallgatók véleménye eltérö, ami az online oktatást illeti. Vannak akik szerint lehetetlenség matematikát online módon elsajátítani:

„Nem lehet online oktatni matematikát és semmilyen tantárgyat, amiben feladatokat kell megoldani és nem olvasás által hozzájutni az ismeretekhez."

„Nem lehet online módon úgy korlátozni a hallgatók figyelmét, mint fizikai kontaktus nyomán. Bárhogy tanítják, nem fognak a hallgatók olyan hatékonyan odafigyelni, mint ahogy az az egyetem falain belül történne. Házépítés, ha az alapot nem építjük jól, később a tető se fog stabilan állni.”

Vannak pozitív vélemények is, amelyek alapján elmondhatjuk, hogy vannak elégedett hallgatók is:

„Szerintem az teljesen mindegy, hogy online vagy offline tanuljuk a matematikát, az a tanár, aki offline jól tartja, az online is vagány órákat tart és megértjük, az aki meg gyenge, az az is marad."

„Én teljesen elégedett vagyok a jelenlegi helyzettel, ha ne adj Isten valamit nem értek, akkor sem kell kétségbe esnem, mivel a tanáraim nagyon segítőkészek."

„Szerintem tökéletes így is, ha valakit érdekel és tanulni akar, az úgy is fog, ha valakit pedig nem érdekel, akkor lehetnek az órák megtartva akárhol.” 


\section{Hallgatók vizsgaeredményeinek összehasonlítása}

\subsection{A kutatás leírása}

A kutatás célja: Egy egyetemi csoport offline és online módon tanított félév során elsajátított matematikai ismeretek összehasonlítása. Az összehasonlítás célja a Partiumi Keresztény Egyetem 1. és 2. évfolyamos hallgatóinak alapszintủ matematikai ismereteinek felmérése, az offline félév, illetve az azt követő online félév végén, valamint az eredmények összehasonlítása. A hallgatók e két félév során alapszintü matematikát tanultak: matematikai analízist, differenciálszámítást, lineáris algebrát és statisztikát

\section{A kutatás résztvevői:}

A kutatásban a Partiumi Keresztény Egyetem 1. és 2. évfolyamos közgazdász hallgatói képezik a mintát. Összesen $\mathrm{N}=79$ hallgatót mértünk fel.

\section{A kutatás hipotézise:}

Feltételezésünk az volt, hogy az online féléves tantárgy során a hallgatók teljesítménye romlott az azt megelóző offline félévhez képest. Indoklásként, azért számítottunk az eredmények romlására, mert nehézkesebb volt a tanítás, a számonkérés, a vizsgáztatás során minden hallgatót két kamerán át felügyeltünk, tehát véleményünk szerint, elég szigorú volt.

\section{A kutatás menete:}

A módszer, amit használtunk az egycsoportos pedagógiai kutatás és a szignifikanciavizsgálat volt.

\subsection{A kutatás eredményei}

Kutatásunk során először megvizsgáltuk a hallgatók matematika vizsgákon való részvételét.

Az 2. ábrán a hallgatók részvételét láthatjuk az offline és az online félév során. Amíg a fizikai jelenlétet igénylő vizsgán mindenki részt vett, addig az online félév során pár hallgató nem jutott el a vizsgáig.

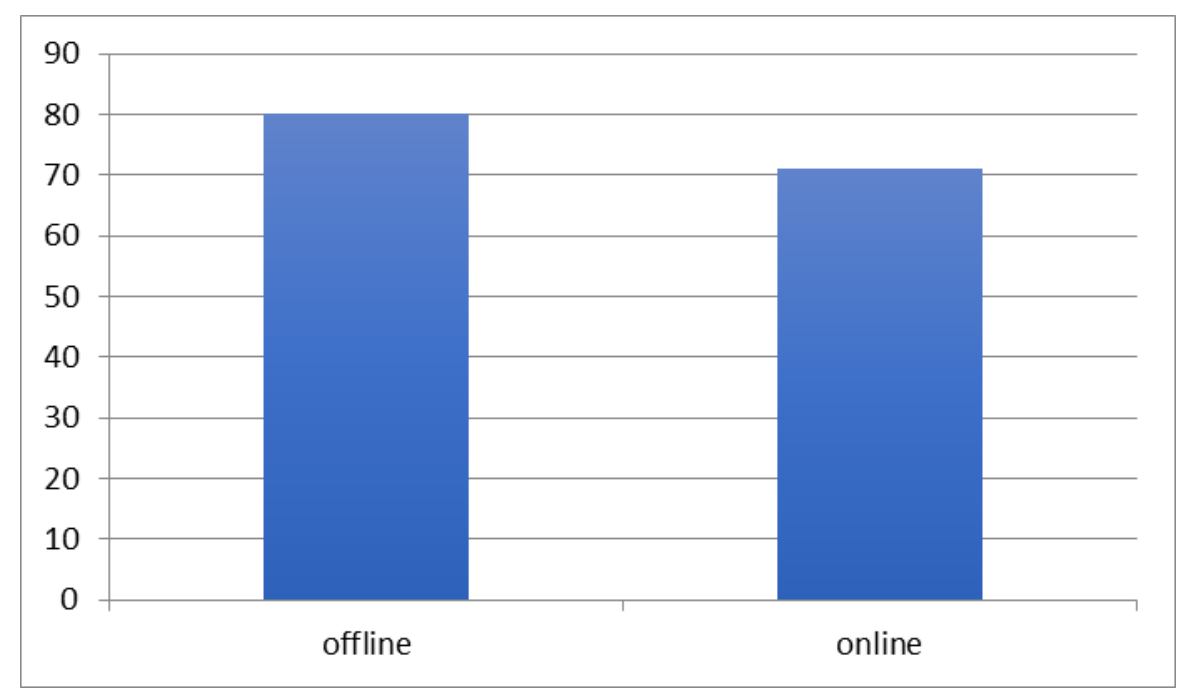

2. ábra A hallgatói csoport részvétele az offline és az online félév során (fő) 
Az első félévben 79 hallgató vizsgázott matematikából, az első félévet teljesítő hallgatók közül 8 hallgató $(10,13 \%)$ lemorzsolódott, nem tett második félévben vizsgát, így az online félévben csak 71 hallgató vizsgázott.

A két teszt eredményének összehasonlításaként elmondhatjuk, hogy az offline félév átlaga 8,08, míg az online félév végén a vizsgajegyek átlaga 7,68 volt.

Első lépésben a két szórás egyenlőségére vonatkozó hipotézisvizsgálatot (F-próbát) végeztük el Excelben. Az F-próba nem mutatott ki szignifikáns különbséget a szórások között. Ha az F- teszt nem mutat ki lényeges eltérést a két adatsor szórása között, akkor alkalmazhatjuk a kétmintás t-teszt egyenlő szórásra vonatkozó változatát.

3. táblázat: F-próba a szórások tesztelésére, illetve kétmintás t-próba

\begin{tabular}{|c|c|c|}
\hline & teljes populáció & százalék \\
\hline Offline félévet teljesítők száma (n) & 79 & $100 \%$ \\
\hline Online félévet teljesítők száma (m) & 71 & $89,87 \%$ \\
\hline F-próba a szórások tesztelésére & 0,353418023 & \\
\hline alfa & 0,05 & \\
\hline n-1 szabadsági fok & 78 & \\
\hline m-1 szabadsági fok & 70 & \\
\hline F(n-1,m-1) táblázatból & 1,45 & \\
\hline & Offline félév & Online félév \\
\hline Létszám & 79 & 71 \\
\hline Átlag & 8,08 & 7,68 \\
\hline korrigált szórás & 1,845105458 & 1,654212354 \\
\hline korrigált szórásnégyzet & 3,404414151 & 2,736418511 \\
\hline t próbastatisztika abszolút értéke & \multicolumn{2}{|c|}{1,391455147} \\
\hline szignifikancia szint alfa & \multicolumn{2}{|l|}{0,05} \\
\hline szabadság fok $n+m-2$ & \multicolumn{2}{|l|}{148} \\
\hline t táblázatból t(0,05) & \multicolumn{2}{|l|}{1,98} \\
\hline
\end{tabular}


A t-próba értéke a 3. táblázatból kiolvasható: $\mathrm{t}=1,39<\mathrm{t}$ kritikus $=1,98$, így a $\mathrm{H}_{0}$ feltevést elfogadjuk. Ez számunkra azt jelenti, hogy a felmérésben szereplő két minta teljesítménye között nincs mérhető szignifikáns különbség.

A 3. táblázat adatait figyelembe véve kijelenthetjük, hogy a vizsgált hallgatói csoport online félévben mutatkozó romlása nem szignifikáns.

\section{Következtetések}

A bemutatott adatok alapján a következő következtetéseket fogalmazhatjuk meg:

A megkérdezett hallgatók nagy többsége alkalmazkodott az online matematika oktatáshoz.

Az előadásokat és szemináriumokat az oktatók többsége, a megkérdezett hallgatók esetében a Google Meet platformon tartják meg, illetve használják még a ZOOM és az MS TEAMS platformokat is. A feladatokat az oktatók az évfolyamok Facebook csoportjában jelölik ki (30,6\%), illetve használják a Google Classroom és az MS TEAMS platformokat is.

A beadandó feladatokat a hallgatók többsége hetente kapja. A feladatokat egyénileg oldják meg és a többség szerint sikerül online módon is elsajátítaniuk a matematikai fogalmakat.

A hallgatók pozitív oldalát is meg tudták fogalmazni a kialakult helyzetnek, mint például a tananyag könnyebb elérhetősége. A hallgatók szerint az online órák egyik előnye, hogy az elméleti ismereteket a tanárok hozzáférhetővé teszik.

A hallgatók úgy nyilatkoztak, hogy az oktatók többsége felkészült a matematika online oktatásra.

A hallgatóknak nem okozott problémát a beadandók időben való elkészítése és a platformok használata.

A teszteredmények összehasonlítása a mi mintánk esetében azt mutatta, hogy nincs szignifikáns különbség az online és az offline félév matematika átlagai között.

\section{Irodalomjegyzék}

Edelhauser, E., Lupu-Dima, L. (2020): Is Romania Prepared for eLearning during the COVID-19 Pandemic? Sustainability; Basel, 12.

Gál, K., Pásztor, R., Székedi, L., Tolnai, T. (2020): Az online oktatás tapasztalatai a felsőoktatásban (elökészületben).

Giordano, P. (2020): How Contagion Works, W\&N Publisher, London.

Gál, K. (2020): Digitális kompetenciák és online oktatás. Plenáris előadás az Erdélyi Múzeum Egyesület által szervezett Magyar Tudomány napja rendezvénysorozat 2020. november 20-i online konferenciáján, https://eme.ro/web/mtne/emetudnap2020 (2020.11.27).

Gleason, J. (2006) Teaching Mathematics Online: A Virtual Classroom - Reflections, JOMA.

Lokanath, M., Gupta, T., Shree, A. (2020): Online Teaching-Learning in Higher Education during Lockdown Period of COVID-19 Pandemic, https://www.sciencedirect.com/science/article/ pii/S266637402030012 (2020.11.10).

Karal, H., Kokoc, M., Colak, C., Yalcin, Y. (2015): A Case Study on Online Mathematics Teaching with Pen-based Technology: Experiences of Two Instructors, Contemporary Educational Technology, 6(4), 319-337. 
Nistor, L., Gergely, O., Sántha, Á., Telegdy, B. (2020): Everything Changes...More or Less. Opinions about the Post -Pandemic World among Ethnic Hungarians from Transylvania (Romania), Acta Universitatis Sapientiae, Social Analysis, 10, 57-76.

\section{Szerzők}

Baranyai Tünde Klára, Babeș-Bolyai University, Satu Mare (Romania). E-mail: baratun@yahoo.com Debrenti Edith, Partium Christian University, Oradea (Romania). E-mail: debrenti.edit@ partium.ro. 